RESEARCH ARTICLE

\title{
Distribution of Virulence Genes in Salmonella Serovars isolated from poultry farms in Kwara State, Nigeria
}

\author{
Ahmed O. Akeem ${ }^{1, *}$, P. H Mamman ${ }^{2}$, M. A. Raji ${ }^{1}$, C. N. Kwanashie ${ }^{2}$, I. A. Raufu ${ }^{1}$ and \\ A. Aremu ${ }^{3}$ \\ ${ }^{I}$ Department of Veterinary Microbiology, University of Ilorin, Ilorin, Kwara State, Nigeria \\ ${ }^{2}$ Department of Veterinary Microbiology, Ahmadu Bello University, Zaria, Kaduna State, Nigeria \\ ${ }^{3}$ Department of Veterinary Pharmacology and Toxicology, University of Ilorin, Ilorin, Kwara State, Nigeria
}

Received: 01/06/2017; Accepted:04/10/2017

\begin{abstract}
This study was aimed at investigating the prevalence and detection of virulence genes in Salmonella isolated from poultry farms in Kwara State, Nigeria. Ten commercial layer farms located in three senatorial districts of the state were sampled. The presence of Salmonella was investigated using standard bacteriological techniques, the isolates obtained were serotyped and polymerase chain reaction (PCR) was used to detect presence of two genes $(f i m \mathrm{~A}$ and $\operatorname{sefC})$ in the isolates. Of the 300 samples collected, $24(8.0 \%)$ were positive for Salmonella; 4 different serovars were identified; Salmonella Larochelle, S. Muenster, S. enterica ser. 6, 7:d, S. enterica ser. 45:d:1,7 and Salmonella Typhimurium, the most frequent being Salmonella Typhimurium (3\%). Varying distribution patterns of the studied genes were observed among the isolates. While, fim A was found in all the $24(100 \%)$ isolates, $s e f \mathrm{C}$ was found only among the Salmonella enterica ser. 45: d: 1,7. The study indicates that the fimA gene is widely distributed among Salmonella irrespective of the serovars. However, the sefC gene appears to be serovar specific. The prevalence of Salmonella in chicken and poultry farms constitutes a major public health concern. Hence, further epidemiological studies are necessary.
\end{abstract}

Keywords: Salmonella, Kwara, Virulence, Poultry farms.

\section{INTRODUCTION}

Poultry industry is one of the major components of the Nigerian economy, serving as a source of income for farmers and a main source of high quality protein for the ever-growing population in Nigeria, due to their affordability and acceptability (Fagbamila et al., 2010; Bettridge et al., 2014). Poultry production plays an important role in the provision of animal protein, this account for about $25 \%$ of local meat production in Nigeria (Agbaje et al., 2010). The poultry industry in Nigeria has been expanding rapidly in past years despite facing many challenges like the global financial crisis, diseases outbreak such as Avian influenza, inadequate credit facilities, low egg production, poor chick quality, poor and low performing breeds, poor weight gain/ feed conversion, feeding and management issues (FAO, 2008; Agada et al., 2014a). The Nigerian poultry industry improved from 150,700 million chickens in 2005 to 192,313 million in 2010 (FAO, 2015). Across different regions of the country, the poultry sector is characterized by a low level of production and weak levels of specialization (FAO, 2008).

Salmonellosis is an important health problem and a major challenge affecting both humans and animals worldwide. Salmonella species are recognized as the most prevalent agent of food poisoning. Salmonellosis in human is often associated with gastroenteritis, which is usually self-limiting. In some cases, particularly in children, pregnant women, infants, the elderly, and immunocompromised patients, Salmonella infection can lead to invasive and focal infections that can be severe (Hald et al., 2007). The sources of nontyphoidal Salmonella are numerous, but most incidences of human foodborne illnesses have been traced to the consumption of poultry meat, eggs, and poultrybased food products (Rabsch et al., 2001; Andrews and Bäumler, 2005). The fact that these pathogens infect the host animals without apparent sickness contributes to high numbers of human infections (Patrick et al., 2004; Dawoud et al., 2011). Modes of transmission and carrier sources of nontyphoidal Salmonella are poorly understood in Africa due to the lack of 
coordinated national epidemiological surveillance systems (Kagambèga et al., 2013).

In poultry, salmonellosis has become an important problem worldwide, causing great economic losses through substantial morbidity, mortality and drop in egg production in addition to huge amounts spent on vaccination and medication (Muhammed et al., 2010; Agada et al., 2014b). Poultry salmonellosis is related to host adapted serovars and remains a major constraint on poultry production in all parts of Nigeria (Garba et al., 2013 and Mamman et al., 2014). Salmonellosis in chicks is usually due to Salmonella Pullorum, the consequence of which is high mortality of both broilers and commercial layers (Idowu et al., 2017). It is characterized by nonspecific signs such as weakness, depression, dehydration, loss of appetite, drooping wings, huddling, somnolence and ruffled feathers. Labored breathing or gasping, as well as diarrhea and pasting of the vent feathers may also be seen (Nógrády et al., 2003). Most signs of salmonellosis in adult birds are thought to be due to Salmonella Gallinarum (Mamman et al., 2014). In addition, zoonotic serovars of Salmonella are harbored in the gastrointestinal tracts of poultry with no apparent signs of illness. Hence, these Salmonella can be excreted in faeces by apparently healthy animals and may be transferred to raw foods of animal origin through contamination during slaughtering and processing (Sanchez et al., 2002).

The virulence of Salmonella species is associated with a combination of chromosomal and plasmid factors (Oliveira et al., 2003). The pathogenecity of an organism in a host is a function of its virulence. Some genes participate in adhesion and invasion such as pef (plasmid encoded fimbriae), spv (Salmonella plasmid virulence) inv (invasion gene) or fim (fimbriae gene) (Alaa and Adnan, 2011). Others play pivotal roles in the survival of organism in the host system- $m g t \mathrm{C}$ (Magnesium transport C) (Blanc-Potard and Groisman 1997) or in the actual manifestation of pathogenic processes for example stn (Salmonella toxin), pip A, B, D (Marcus et al., 2000). Bacterial adherence (Kurkkonen et al., 1993) is considered to be a prerequisite for infection, and there are evidences that many bacteria have surface processes, such as fimbriae (Clegg et al., 1985; Aslanzadeh and Paulissen, 1992) or pili, that facilitate attachment to particular receptors on the epithelial cell surface, to urinary tract or intestinal mucus. Although certain strains of $E$. coli fimbriae are known to be important for virulence, only type 1 fimbriae (fimA) have been implicated in Salmonella pathogenicity.

Control of Salmonella infection will not only culminate into expansion of poultry industry in Nigeria but also lead to reduction in the threat of foodborne illness due to Salmonella in human. Effective prevention and control measures cannot be undertaken unless the status of the disease and epidemiology are well investigated. Therefore, the present study was undertaken to investigate the prevalence and detect the virulence genes in Salmonella serovars in selected layer farms in Kwara state.

\section{MATERIALS AND METHODS}

\section{Study area}

The study was carried out in Kwara State, Nigeria. Kwara State is located between latitudes $\left(8^{\circ} 30^{\prime} \mathrm{N}\right)$ and longitudes $\left(5^{\circ} 00^{\prime} \mathrm{E}\right)$. The state shares a common internal boundary with Niger State in the North, Kogi State in the East, Oyo, Ekiti and Osun States in the South and an international boundary with the Republic of Benin in the west. Kwara State is a summer rainfall area, with an annual rainfall range of $1,000 \mathrm{~mm}$ to $1,500 \mathrm{~mm}$. The rainy season begins at the end of March and lasts until early September, while the dry season begins in early October and ends in early March. Temperature is uniformly high and ranges between $25^{\circ} \mathrm{C}$ and 30 ${ }^{0} \mathrm{C}$ in the wet season throughout the season except in July - August when the clouding of the sky prevents direct insolation (heatstroke) while in the dry season it ranges between $33{ }^{\circ} \mathrm{C}$ to 34 ${ }^{0} \mathrm{C}$ (NBS, 2010).

\section{Study strategy}

The study involved sampling for Salmonella in layers farms that agreed to participate in the study. Two Local Governments from each of the three senatorial districts of the state were selected based on their commercial poultry production according to data obtained from the state veterinary services. The Local Governments were Ilorin South, Ilorin-West, Moro, Offa, Irepodun and Asa. Twelve farms were selected randomly by balloting for the study, two farms per Local Government; however, two farms declined. 


\section{Sample collection}

Layer farms were visited across the selected Local Governments, and the following samples were collected: cloacal swabs, litters composed of faeces mixed with saw dust (from deep litters system), non-medicated water and poultry feeds. Twenty-seven (27) cloacal swabs were taken per farm with one each from a bird, liters $(n=1 /$ farm), water $(\mathrm{n}=1 /$ farm $)$ and feed $(\mathrm{n}=1 /$ farm $)$ making a total of 300 samples. Cloacal swabs were collected using sterile swabs, $25 \mathrm{~g}$ of wet litters, approximately $50 \mathrm{~g}$ of feed and $100 \mathrm{ml}$ of untreated water were collected per farm. All the samples were labelled properly and kept in a cool box containing ice packs and transported, within five (5) hours, to Veterinary microbiology laboratory, University of Ilorin for analysis.

\section{Sample Processing}

Samples were pre-enriched in buffered peptone water (Lab M, Lancashire, UK) at the ratio of 1:10 sample to broth incubated at $37{ }^{\circ} \mathrm{C}$ for 24 hours. $1 \mathrm{ml}$ of the pre-enriched broth was inoculated in $9 \mathrm{ml}$ of Selenite-F (Oxoid, Hampshire, UK) and Rappaport-Vassiliadis (Oxoid, Hampshire, UK) incubated for 24 hours at $37{ }^{\circ} \mathrm{C}$ and $42{ }^{\circ} \mathrm{C}$, respectively (ISO, 2002; OIE, 2012).

\section{Isolation, Identification, and Serotyping of} Salmonella

The selective broths (Selenite F and RappaportVassiliadis) were subcultured onto Salmonella-
Shigella agar (Oxoid, Hampshire, UK) and Xylose Lysine Deoxycholate agar (Oxoid, Hampshire, UK) and were incubated aerobically at $37{ }^{\circ} \mathrm{C}$ for 24 hours. The presumptive Salmonella isolates on XLD (pink/red with/without central black spot due to hydrogen sulphide production) and SSA (transparent colonies with black centre) were then subjected to standard biochemical tests (Andrews, 1992; MacFaddin, 2002). Isolates biochemically identified as Salmonella were streaked on nutrient agar slants and shipped to the WHO National Salmonella and Shigella Center, Bangkok, Thailand, for serotyping according to the Kauffmann-White Scheme (Raufu et al., 2013; Issenhuth-Jeanjean et al., 2014).

\section{Polymerase Chain Reaction (PCR) analysis of the isolates}

\section{DNA extraction}

DNA extraction was carried out in accordance with manufacturer's instruction using ZR fungal/bacterial DNA miniPrep ${ }^{\mathrm{TM}}$ (Zymo Resarch Corp. USA) at Department of Veterinary public health laboratory, University of Ilorin.

\section{Primers}

The sets of primer pairs used in the PCR assay are as shown in table 1 . The primers were synthesized at Inqaba biotech (QN 201502628) South Africa.

Table 1: Primers sequence for PCR amplification.

\begin{tabular}{ccccc}
\hline Primer & $\begin{array}{c}\text { Sequence: F-(5'-3') } \\
\text { R-(3'-5') }\end{array}$ & $\begin{array}{c}\text { Product size } \\
(\mathbf{b p})\end{array}$ & Reference \\
\hline fim A & $\mathbf{F}$ & CCT TTC TCC ATC GTC CTG AA & 670 & Huguette et al., 1996 \\
& $\mathbf{R}$ & CA CGA TCC GTC TAT TGT TGG & & \\
Sef $\mathbf{C}$ & $\mathbf{F}$ & GCGAAAACC AAT GCG ACT GTA & 1103 & Murugkar et al., 2003 \\
& $\mathbf{R}$ & CCCACC AGA AAC ATT CAT CCC & & \\
\hline
\end{tabular}




\section{PCR assay}

PCR analysis was carried out at Bioscience Laboratory unit of International Institute of Tropical Agriculture (IITA), Ibadan, Nigeria. The PCR reaction contained a final volume of 25 $\mu \mathrm{L}$ which included $12.5 \mu \mathrm{l}$ master mix (Inqaba Biotech, S. Africa) containing (5 U/ul) Taq DNA polymerase, $2.5 \mathrm{mM}$ each of dATP, dCTP, dTTP and dGTP, $50 \mathrm{mM} \mathrm{MgCl}_{2}$ and PCR buffer, 1.25 $\mu 1(1 \mu M)$ each of forward and reverse primers and $2.5 \mu \mathrm{l}$ of template DNA (100ng/ $\mu \mathrm{l}$ DNA) and $7.5 \mu \mathrm{l}$ of deionized water. The cocktail was used for each sample. The reaction was performed in a thermocycler (Perkin-Elmer, USA) in 40 cycles of initial denaturation $\left(94{ }^{\circ} \mathrm{C}\right.$ for 5 minutes), denaturation $\left(94{ }^{0} \mathrm{C}\right.$ for 30 seconds), primer annealing $\left(55{ }^{0} \mathrm{C}\right.$ for 45 seconds) and primer extension $\left(72{ }^{\circ} \mathrm{C}\right.$ for 45 seconds) followed by final extension at $72{ }^{\circ} \mathrm{C}$ for 7 minutes. Fifteen microliters $(15 \mu \mathrm{l})$ of each PCR products were loaded on $2.0 \%$ agarose gel containing $0.5 \mu \mathrm{l} / \mathrm{ml}$ ethidium bromide (Pharmacia, Sweden). The gel picture was captured using Gel doc 2000 documentation system (Pharmacia, Sweden).

\section{RESULTS}

\section{Isolation of Salmonella}

Of the 300 samples collected, $24(8.0 \%)$ were positive for Salmonella. The different Salmonella serovars and their rates of isolation from different sources are as shown in table 2 . Salmonella Typhimurium was the most frequently isolated serovar from $2(20 \%)$ of feed and water samples each and 5(1.9\%) of the cloacal swabs. Salmonella Muenster was only isolated from 2 water samples $(20 \%)$.

\section{Detection of Salmonella genes using PCR}

In this study, PCR assay was performed for the detection of two virulence genes. The fimA gene was detected in all the isolates by demonstrating the presence of $670 \mathrm{bp}$ PCR product (Figure 1.0). The sefC gene was detected by the presence of $1103 \mathrm{bp}$ PCR product (Figure 2.0) only in 20.8 $\%(5 / 24)$ of the isolates confirmed to be Salmonella enterica ser. 45:d:1,7 serovars isolates (Table 3).

Table 2: Different Salmonella serovars and rates of their isolation from different sources.

\begin{tabular}{lccccc}
\hline \multicolumn{1}{c}{ Serovars } & \multicolumn{5}{c}{ Sample Source } \\
\cline { 2 - 6 } & Cloacal swabs & Litters & Feeds & Water & Total \\
\hline Larochele & $0(0)$ & $1(10.0)$ & $0(0)$ & $1(10.0)$ & $2(0.7)$ \\
Muenster & $0(0)$ & $0(0)$ & $0(0)$ & $2(20.0)$ & $2(0.7)$ \\
S. enterica ser. 6,7 d & $3(1.1)$ & $0(0)$ & $3(30.0)$ & $0(0)$ & $6(2.0)$ \\
S. enterica ser. 45,d 1,7 & $2(0.7)$ & $1(10.0)$ & $2(20.0)$ & $0(0)$ & $5(1.7)$ \\
Typhimuruim & $5(1.9)$ & $0(0)$ & $2(20.0)$ & $2(20.0)$ & $9(3.0)$ \\
Total & $10(3.7)$ & $2(20.0)$ & $7(70.0)$ & $5(50.0)$ & $24(8.0)$ \\
No. of samples examined & 270 & 10 & 10 & 10 & 300 \\
\hline
\end{tabular}

Table 3: Distribution of fim A and sef $\mathrm{C}$ genes among Salmonella isolated from poultry farms.

\begin{tabular}{lccc}
\hline \multicolumn{1}{c}{ Serotype } & No. of isolates & \multicolumn{2}{c}{ No. positive for virulence genes } \\
\cline { 3 - 4 } & & fim A & sef C \\
\cline { 2 - 4 } S. Larochele & 2.0 & 2.0 & 0 \\
S. Muenster & 2.0 & 2.0 & 0 \\
S. enterica ser. $6,7 \mathrm{~d}$ & 6.0 & 6.0 & 0 \\
S. enterica ser. 45,d 1,7 & 5.0 & 5.0 & 5.0 \\
S. Typhimuruim & 9.0 & 9.0 & 0 \\
\hline Total & 24.0 & 24.0 & 5.0 \\
\hline
\end{tabular}



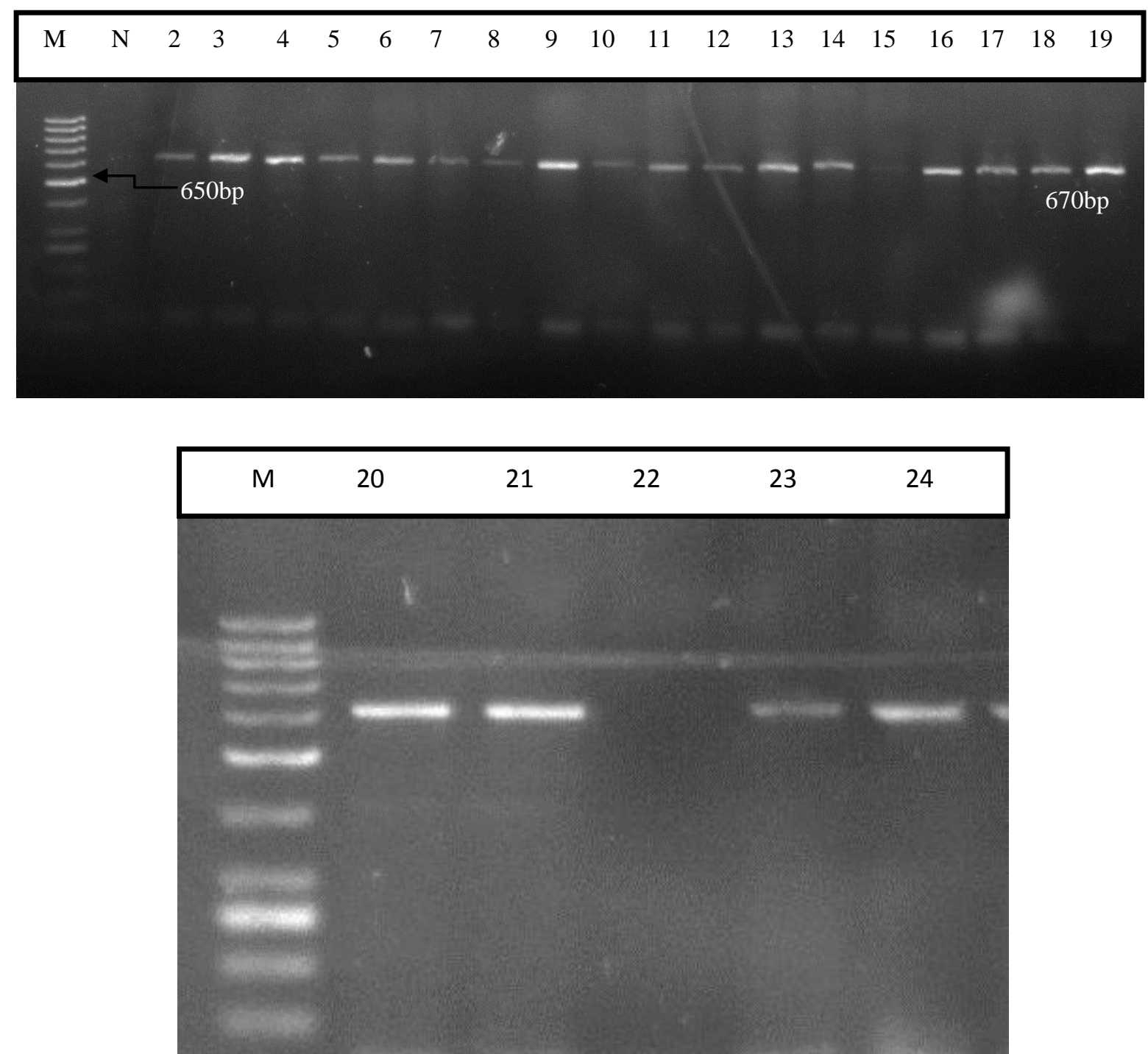

Figure 1: Detection of fimA gene by PCR. Lane M-(50 bp) DNA ladder molecular weight marker, lane N-negative control (deionized water), 2 to 24 -Test isolates.

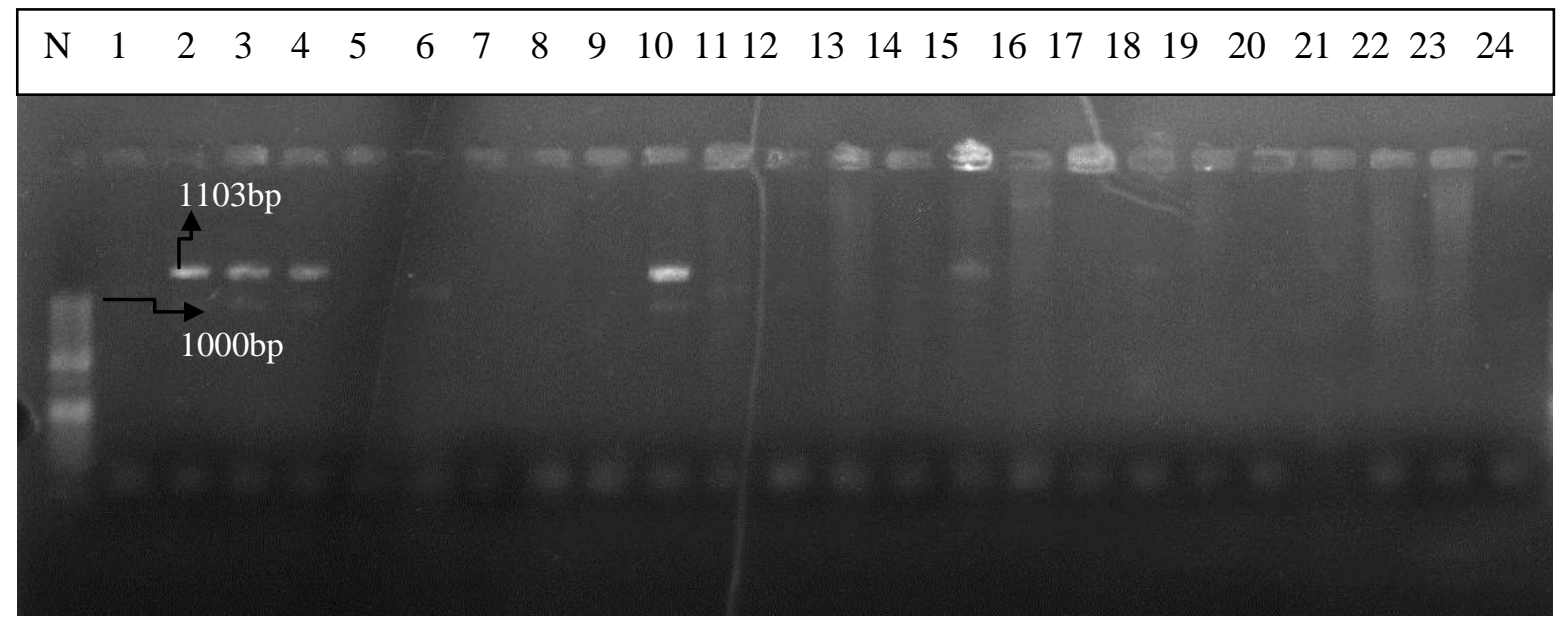

Figure 2: Detection of $s e f C$ gene PCR. Lane M-(50 bp) DNA ladder molecular weight marker, lane N-negative control (deionized water), 1 to 24 -Test isolates. 


\section{DISCUSSION}

Salmonellosis is one of the major zoonotic foodborne diseases worldwide (Kagambèga et $a l ., 2013$ ) and it's prevalence in animals poses a continuous threat to man (Muhammad et al., 2010). Several Salmonella serovars were isolated from all the sample sources examined in this study and many of these Salmonella serovars are known to be pathogenic to man. The isolation rate of Salmonella serovars in this study correlates with earlier study by Muhammad et al. (2010) which reported isolation rate of $9.0 \%$ from farms in Jos, Plateau state, Nigeria. It is however higher than $2.8 \%$ reported in Caribbean countries (Adesiyun et al., 2014)

Salmonella Typhimurium was the most frequent isolated serovar and this agree with previous work which also reported this serovar as one of the common serovars isolated from poultry in Nigeria (Orji et al., 2005). The isolation of invasive Salmonella such as serotype Typhimurium and other pathogenic salmonellae in this study highlights the risk of health hazards to consumers as contaminated poultry and poultry products may serve as source of infection to human food chain (Doaa, 2013).

Polymerase chain reaction (PCR) has become a potentially powerful alternative technique in microbiological diagnostics due to the fact that it is fast, simple, accurate, and reproducible (Pickup et al., 2003). In this present study, fimA gene was detected in all the 24 Salmonella isolates. These finding is in agreement with earlier reports by Huguette $e t$ al. (1996), Alaa and Adnan (2011) which both found that the fimA gene contains sequences unique to Salmonella isolates and demonstrated that this gene is suitable for PCR target for the detection of Salmonella strains. Bacterial adherence (Kurkkonen et al., 1993) is considered to be a baseline requirement for infection, and there is evidence that many bacteria have surface appendages, such as pili or fimbriae (Clegg et al., 1985; Aslanzadeh and Paulissen, 1992), that facilitate their binding to specific receptors on the epithelial cell surface, or intestinal mucus. Although certain types of Escherichia coli fimbriae are known to be important for virulence, only type 1 fimbriae (fim $A$ ) have been implicated in Salmonella pathogenicity.

Salmonella Enteritidis fimbriae 14 (SEF14) is encoded by the sef operon, which contains sefC gene. It contains 4 major protein subunits SefA, SefB, SefC, and SefD. SEF14 plays important role in the ability of Salmonella to colonize Peyer's patches and in the adhesion and invasion of epithelial cells of the host intestine (Castilla et al., 2006). In the present study, the sefC gene was detected in $5(20.8 \%)$ of the isolates which were confirmed to be Salmonella enterica ser. 45:d:1,7 by serotyping. The present finding does not agree with the findings of Rahman (1999) and Murugkar et al. (2003) which showed that except for strains of $S$. enteritidis and $S$. gallinarum, none of the other serotypes (S. Typhimurium, S. Newport, S. Kentucky, S. Weltevreden and S. Indiana) tested were found to contain sefC gene. These differences might be due to the fact that the serotype shown to contain this gene in our present study was not part of the serovars studied by Rahman (1999) and Murugkar et al. (2003) or might be due to evolution of new gene in this serovar. Future studies are needed to confirm this hypothesis.

\section{CONCLUSION}

Contamination of chicken farms with Salmonella indicate generally poor infrastructure and low biosecurity measures in farms in the state. The study reaffirmed the applicability of PCR amplification of fimA for identification of Salmonella species and reported for the first time the presence of SefC gene in Salmonella ser. $45: \mathrm{d}: 1,7$.

\section{ACKNOWLEDGEMENT}

We would like to thank all laboratory technologists at the Department of Veterinary Microbiology, University of Ilorin and Bioscience Unit, IITA, Ibadan for the technical assistance.

\section{Conflicts of interest: none}

\section{REFERENCES}

Adesiyun, A., Webb, L., Musai, L., Louison, B., Joseph, G., StewartJohnson, A., Samlal, S. and Rodrigo, S. (2014). Survey of Salmonella contamination in chicken layer farms in three Caribbean countries. Journal of Food Protection, 77: 1471-1480.

Agada, G. O. A., Abdullahi, I. O., Aminu, M., Odugbo, M., Chollom, S. C., Kumbish, P. R. and Okwori, A. E. J. (2014a). Prevalence and Antibiotic Resistance Profile of Salmonella Isolates from Commercial Poultry and Poultry 
Farm-handlers in Jos, Plateau State, Nigeria. British Microbiology Research Journal, 4: 462 479.

Agada, G. A., Abdullahi, I. O., Aminu, M., Odugbo, M., Chollom, S. C., Okeke, L. A. and Okwori, A. E. J. (2014b); Prevalence and risk factors associated with Salmonella species contamination of commercial poultry farms in Jos, Plateau State, Nigeria. World Journal of Biology and Biological Science, 2: 49-61.

Agbaje, M., Davies, R., Oyekunle, M. A., Ojo, O. E., Fasina, F. O. and Akinduti P. A. (2010) Observation on the occurrence and transmission pattern of Salmonella Gallinarumin in commercial poultry farms in Ogun State, South Western Nigeria. African Journal Microbiological Research, 4: 796-800.

Alaa, A. J. and Adnan, H. A. (2011). Detection of fimA and fimC genes of Salmonella isolates by using Polymerase Chain Reaction. Journal of Basrah Researches (Sciences), 37: 27-36.

Andrews, H. L. and Bäumler, A. J. (2005). Salmonella species. Pages 327-339 in Foodborne Pathogens: Microbiology and Molecular Biology. P. M. Fratamico, A. K. Bhunia, and J. L. Smith, ed. Caister Academic Press, Norwich, UK.

Andrews, W. (1992). Manuals of food quality control. 4. Microbiological analysis. FAO food and nutrition paper 14/4, Food and Agriculture Organization, Rome 1: 27-48.

Aslanzadeh, J. and Paulissen, L. J. (1992). Role of the type 1 and type 3 fimbriae adherence and pathogenic of Salmonella enteritidis in mice. Microbiology and Immunology, 36: 351-359.

Bettridge, J.M., Lynch, S.E., Brena, M.C., Melese, K., Dessie, T., Terfa, Z.G., Desta, T.T., Rushton, S., Hanotte, O., Kaiser, P., Wigley, P. and Christley, R.M. (2014). Infection-interactions in Ethiopian village chickens. Preventive Veterinary Medicine, 117 (2): 358-366. DOI: 10.1016/j.prevetmed.2014.07.002

Blanc-Potard, A. B. and Groisman, E. A. (1997) The Salmonella selC locus contains a pathogenicity island mediating intramacrophage survival. EMBO Journal, 16: 5376-85.

Castilla, K. S., Astolfi, C. S., Moreno, A. M., Nunes, I. A., and Piantino, F. A. J. (2006). Distribution of virulence genes sefC, pefA and $s p v \mathrm{C}$ in Salmonella Enteritidis phage type 4 strains isolated in Brazil. Brazilian Journal of Microbiology, 37: 135-139.

Clegg, S., Pruckler, J. and Purcell, B. K. (1985). Complementation analyses of recombinant plasmids encoding type 1 fimbriae of members of the family Enterobacteriaceae. Infection and Immunology, 50: 338-340.

Dawoud, T. M., Hererra, P., Hanning, I., Kwon, Y. M. and Ricke, S. C. (2011). In vitro invasion of laying hen ovarian follicles by Salmonella
Enteritidis strains. Poultry Science, 90: 11341137.

Doaa, M. A. E. (2013). D etection giblets of S almonella typhimurium in retail chicken meat and chicken. Asian Pacific Journal of Tropical Biomedicine, 3(9): 678-681.

Fagbamila, I., Kabir, J., Abdu, P., Omeiza, G., Ankeli P., Ngulukun, S., Maryam, M. and Jarlath, U. (2010). Antimicrobial screening of commercial eggs and determination of Tetracycline residue using two microbiological methods. International Journal of Poultry Science, 9: 959-962.

Food and Agricultural Organization (2008). Assessment of the Nigerian poultry market chain to improve biosecurity. Available: http://www.fao.org/3/a-ak778e.pdf.

Food and Agricultural Organization (FAO) (2015). Data Source: FAOSTAT | FAO Statistics Division 2015 | December 2015.

Garba A., Turaki, U. A., Abdurrahman, A., Goji, J. N., Bolajoko, I.J. Barde, Ahmed A., Sa'Adatu, I. and Abdullahi, A. S. (2013). The Threat of Salmonellosis to Commercial Poultry Production in Adamawa State, Nigeria. Sokoto Journal of Veterinary Sciences, 8: 50-52.

Hald, T., Lo Fo Wong, D. M. and Aarestrup, F. M. (2007). The attribution of human infections with antimicrobial resistant Salmonella bacteria in Denmark to sources of animal origin. Food borne Pathogen and Disease, 4: 313-326.

Huguette, J., Cohen, Subbaiah, M., Mechanda and Wei, L. (1996). PCR amplification of the fimA gene sequence of Salmonella Typhimurium, a specific method for detection of Salmonella spp. Applied and Environmental microbiology, 62: 4303-4308.

Idowu O. F., Lisa B., Marzia M., Jacob K., Sati S. N., Paola Z., Antonia A. L., Monica L., Paul, A. A., Junaidu, K., Jarlath, U., Antonia, R. and Maryam, M. (2017). Salmonella serovars and their distribution in Nigerian commercial chicken layer farms. $\quad P L O S \quad O N E, \quad$ 12(3): e0173097.doi:10.1371/journal.

International Organization of Standardization (ISO) 6579 (2002). Microbiology general guidelines on methods for the detection of Salmonella. International organization of standardization, Geneva, Switzerland

Issenhuth-Jeanjean, S., Roggentin, P., Mikoleit, M., Guibourdenche, M., de Pinna, E., Nair, S., Fields, I. P. and Weill, F. (2014) . Supplement 20082010 (no. 48) to the White-Kauffmann-Le Minor scheme. Research Microbiology, 165: 526-530.

Kagambèga, A., Lienemann, T., Aulu, L., Traoré, A. S., Barro, N., and Siitonen, A. (2013). Prevalence and characterization of Salmonella enterica from the feces of cattle, poultry, swine and hedgehogs in Burkina Faso and their comparison to human Salmonella isolates. BMC Microbiology, 13: 25356. 
Kurkkonen, M. T., Raunio, T., Virkola, R., Lahteemaki, K., Makela, P. H., Klemm, P., Clegg, S. and Korhonen T. K. (1993). Basement membrane carbohydrate as a target for adhesion binding of type 1 fimbriae of Salmonella Enteritidis and Achillea to lamini. Molecular Microbiology, 7: 227-237.

MacFaddin, J. F. (2002). Biochemical tests for identification of medical bacteria. Williams and Wilkins, New York

Mamman, P. H., Kazeem, H. M., Raji, M. A., Nok, A. J. and Kwaga, J. K. (2014). Isolation and Characterization of Salmonella Gallinarum from Outbreaks of Fowl Typhoid in Kaduna State, Nigeria. International Journal of Public Health and Epidemiology, 3: 082-088

Marcus, S. L., Brumell, J. H., Pfeifer, C. G. and Finlay, B. B. (2000). Salmonella pathogenicity islands: big virulence in small packages. Microbial Infection, 2: 145-156

Muhammad, M., Muhammad, L. U., Ambali, A., Mani, A. U., Azard, S., and Barco, L. (2010). Prevalence of Salmonella associated with chick mortality at hatching and their susceptibility to antimicrobial agents. Veterinary Microbiology, 140: 131-135.

Murugkar, H.V., Rahman, H. and Dutta, P. K. (2003). Distribution of virulence genes in Salmonella serovars isolated from man \& animals. Indian Journal of Medicine Research, 117: 66-70.

National Bureau of Statistics (NBS) (2010). Commercial Agriculture Development Project (CADP),. NBS/CADP Baseline Survey Report. 5: $5-46$.

Nógrády, N., Imre, A., Rychlik, I., Barrow, P.A. and Nagy, B., (2003). Growth and colonisation suppression of Salmonella enterica serovar Hadar in vitro and in vivo. FEMS Microbiology Letters, 218: $127-133$.

Office International des Epizooties (OIE) (2012). Fowl typhoid and pullorum disease. In:
Terrestrial manual. Office International des Epizooties, Paris, France, 3-5.

Oliveira S. D., Rodenbusch C. R., Michael G. B., Cardoso M. I. R., Canal C. W. and Brandelli A. (2003). Detection of virulence genes in Salmonella Enteritidis isolates from different sources. Brazilian Journal of Microbiology, 34: 123-124.

Orji, M. U., Onuigbo, H. C., and Mbata, T. I. (2005). Isolation of Salmonella from poultry droppings and other environmental sources in Awka, Nigeria. International Journal of Infectious Diseases, 9: 86-89.

Patrick, M. E., Adcock, P. M., gomez, T. M., Altekruse, S. E., Holland, B. H., Tauxe, R. V. and Swendlow, D. L. (2004). Salmonella Enteritidis infections, United States, 1985-1999. Emerging Infectious Diseases, 10: 1-7.

Pickup, R. W., Rhodes, G. and Hermon-Taylor, J. (2003). Monitoring bacterial pathogens in the environment: advantages of a multilayered approach. Current Opinion Biotechnology, 14: 319-325.

Rabsch, W., Tschäpe, H. and Bäumler, A. J. (2001). Non-typhoidal salmonellosis: Emerging problems. Microbes and Infection, 3: 237-247.

Rahman H. (1999). Prevalence of enterotoxin gene (stn) among different serovars of Salmonella. Indian Journal of Medicine Research, 110: 43-6.

Raufu, I., Bortolaia, V., Svendsen, C. A., Ameh, J. A., Ambali1, A. G., Aarestrup, F. M. and Hendriksen, R. S. (2013). The first attempt of an active integrated laboratory-based Salmonella surveillance programme in the north-eastern region of Nigeria. Journal of Applied Microbiology, 115: 1059-1067.

Sanchez, S., Hofacre, C. L., Lee, M. D., Maurer, J. J. and Doyle, M. P. (2002). Animal sources of salmonellosis in humans. Journal of American Veterinary Association, 211: 492-497. 